\title{
The Effects of Environmental Factors on Artemia Population in Tuz Lake (Central Anatolia, Turkey)
}

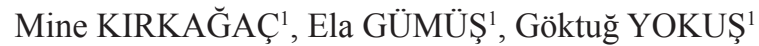

\begin{abstract}
Artemia population was investigated monthly between November 2013-July 2014 in Tuz Lake and 5 stations were selected; one from the west side, 4 from the east side of the Lake. Some physical and chemical parameters (depth, secchi depth, water temperature, dissolved oxygen, conductivity and $\mathrm{pH}$ were measured monthly and ammonium nitrogen, nitrite nitrogen, nitrate nitrogen, orthophospate, alkalinity, total hardness, chlorophyll $a$, silicate concentrations were measured seasonally) of the Lake water were also determined. Artemia was found only once at the second sampling on March, in the 5th station in metanauplius form about $3,67 \times 10^{3}$ individual.m, cycts were not found during the research. At the stations, chlorophyll a concentration $\left(0.18-2.70 \mu \mathrm{g} \mathrm{l}^{-1}\right)$ and orthophosphate concentration $\left(0-1.07 \mathrm{mg}^{-1}\right)$ values were found to be quite low, and ammonium nitrogen concentration values varied between $1.25 \mathrm{mg} \mathrm{l}^{-1}$ and $3.25 \mathrm{mg} \mathrm{l}^{-1}$. It is thought that Uluirmak and Peceneközü Brooks and DSI Drainage Channel flowing into the basin of Tuz Lake affected the ammonium-nitrogen and orthophosphate concentrations in the Lake. The long-term investigations of the biological, physical and chemical properties of Tuz Lake will contribute to revealing the factors that caused to the present condition of the Lake.
\end{abstract}

Key Words: Artemia, abiotic factors, biotic factors, Tuz Lake

\section{Tuz Gölü’nde Çevresel Faktörlerin Artemia Populasyonu'na Etkisi}

ÖZET: Artemia popülasyonu Tuz Gölü’nün batısında 1, doğusunda 4 olmak üzere seçilen toplam 5 istasyonda, Kasım 2013- Temmuz 2014 yılları aylık olarak arasında araştırılmıştır. Eş zamanlı olarak gölün bazı fiziksel ve kimyasal özellikleri de (derinlik, seki derinliği, su sıcaklığı, çözünmüş oksijen, kondüktivite ve pH ölçümleri aylık, amonyum azotu, nitrit azotu, nitrat azotu, ortofosfat, alkalinite, toplam sertlik, klorofil $a$, silikat konsantrasyonları mevsimlik olarak) belirlenmiştir. Araştırma süresince kiste rastlanmazken, Artemia sadece bir kez Mart ayındaki ikinci örneklemede 5. istasyonda metanauplius formunda $\left(3,67 \times 10^{3}\right.$ birey. $\left.\mathrm{m}^{-3}\right)$ bulunmuştur. Araştırma süresince, özellikle su sıcaklığı, çözünmüş oksijen ve tuzluluk değerleri son 20 yıla ilişkin verilerle karşılaştırıldığında artış göstermiş, su derinliği ise gölün tamamında azalmıştır. İstasyonlarda, klorofil a konsantasyonu (0.18-2.70 $\left.\mu \mathrm{g} \mathrm{l}^{-1}\right)$ ile ortofosfat konsantrasyon değerleri $\left(0-1.07 \mathrm{mg} \mathrm{l}^{1-1}\right)$ oldukça düşük düzeylerde bulunmuş, amonyum azotu konsantrasyonu değerleri ise 1.25-3.25 $\mathrm{mg} \mathrm{l}^{-1}$ arasında değişim göstermiştir. Tuz Gölü'ne akan Uluırmak, Peçeneközü Dereleri ve DSİ Drenaj Kanalının göle ilişkin amonyum-azotu ve ortofosfat konsantrasyonlarını etkilediği düşünülmektedir. Tuz Gölü’nün biyolojik, fiziksel ve kimyasal özelliklerinin uzun süreli araştırılması, gölün bugünkü durumuna neden olan faktörlerin de ortaya konmasına katkı sağlayacaktır.

Anahtar kelimeler: Abiyotik faktörler, Artemia, biyotik faktörler, Tuz Gölü

\footnotetext{
Ankara Üniversitesi, Ziraat Fakültesi, Su Ürünleri Mühendisliği, Ankara, Türkiye

Sorumlu yazar/Corresponding Author: Mine KIRKAĞAÇ, kirkagac@agri.ankara.edu.tr
} 


\section{INTRODUCTION}

Salinity and aquatic biodiversity are inversely related in lake waters. So, salinity degree is the the determinant of the community structure in water bodies (Williams, 1998, Demir, 2007). In hypersaline (salinity $>50 \mathrm{~g}^{-1^{-1}}$ ) lakes, the brine shrimp Artemia Leach, 1819 is the dominant zooplankton. Their grazing activity is very important for controlling the water clarity or holobacteriums and algal blooms, especially for the salt lakes where salt processing and refining are the main task. The salt quality is affected and so the bigger salt crystalize is ensured by Artemia grazing activity (Persoone and Sorgellos, 1980). Beside, it is also very important live feed for marine fish larvae.

Tuz Lake is located in the Central Anatolia. It has a closed basin without outflowing. Its saline concentration is about $32 \%$ and with this salinity degree it is the second one following Dead Sea in the World. The salt supplied form Tuz Lake is about 70\% of Turkey's requirement (Kılıç and Uyanık, 2001). There are two regions with different chemical and physical conditions in the lake; as shallow and deep regions, their salinities are about 300-350 g..$^{-1}$ and 80 g. $1^{-1}$, respectively (Uygun and Şen, 1978). In recent years, global warming is threatened the Lake and its area is getting smaller. In 2000 years, Tuz Lake was declared a specially protected area (Anonymous, 2007).
The presence of Artemia population was reported from the deep region at the east side of Tuz Lake in a $10 \mathrm{~km}$ coastline in 1994-1995 years, their highest abundance was about 106-114 individual. $\mathrm{m}^{-3}$ in May. By the increasing salinity and temperature in the lake, the abundance decreased in June (Başbuğ and Demirkalp,1997; Başbuğ, 1999).

Global warming threatened most of the saline lakes, especially their biological features. This study was carried out to put forward the case of a saline lake from the Central Anatolia of Turkey. So the present status of Artemia population was aimed to determined in related to the environmental factors in Tuz Lake.

\section{MATERIAL AND METHODS}

\section{Study area}

Tuz Lake ( $\left.38^{\circ} 44^{\prime} \mathrm{N} 33^{\circ} 23^{\prime} \mathrm{E}\right)$ located in the Central Anatolia, it is tectonic lake and fed by ground waters and surface waters (Fig 1). It has no outlet. In the most of the years it is very shallow. Its surface area is about $1700 \mathrm{~km}^{2}$, the lenght and width of the lake are $90 \mathrm{~km}$ and $35 \mathrm{~km}$, respectively. During the summer the lake dries up exposing an average of $30 \mathrm{~cm}$ thick salt layer in August. The Lake is also special for some birds for their breeding (Anonymous, 2007).

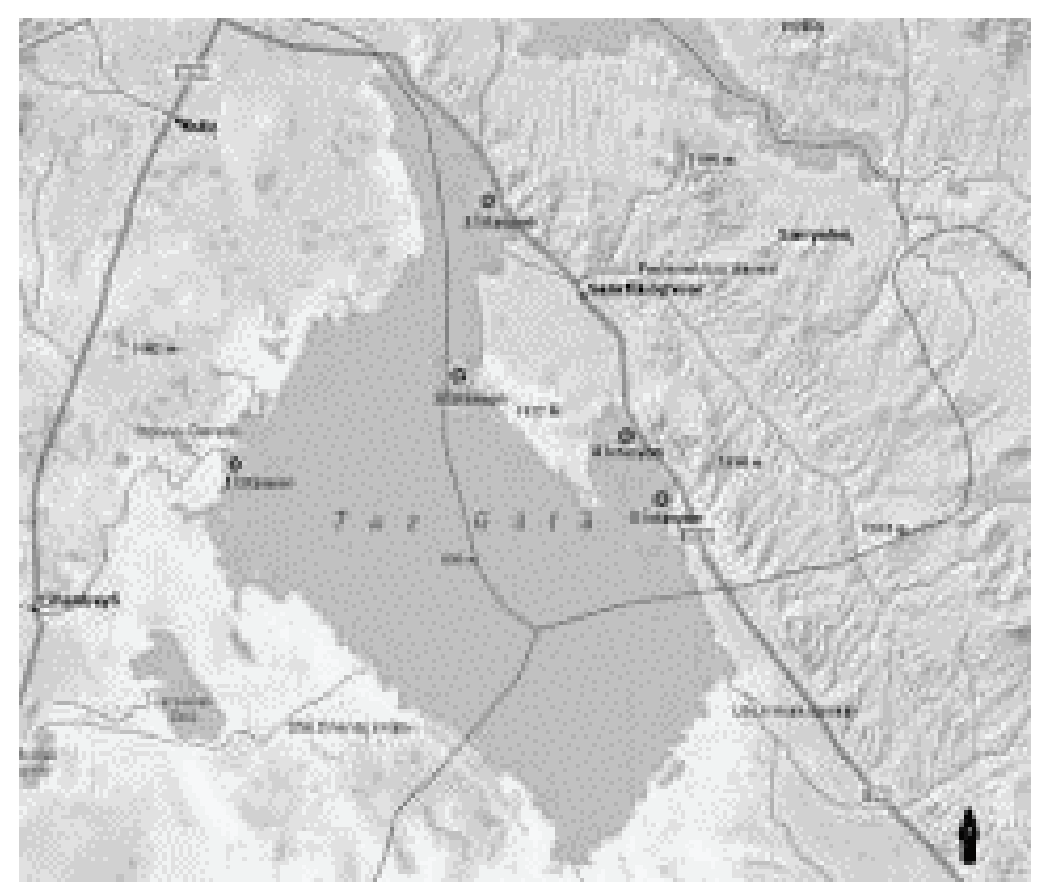

Figure 1. Tuz Lake and sampling stations 


\section{Collection of Samples}

The research was carried out between July 2013 and July 2014. Samples were collected from 5 stations in the Lake. Samples for Artemia were collected with 15 days intervals in spring and summer, monthly in autumn and winter. A plankton net with $55 \mu \mathrm{m}$ mesh size was used horizontally to collect the samples. Those samples were preserved in $4 \%$ formaldehyde solution (Tanyolaç, 2006). Samples were examined, identified and counted under binoculer and inverted microscopes (Edmondson, 1959; Edmondson and Winberg, 1971; Koste, 1978; Mc Cauley, 1984; Wetzel and Likens, 1991; Smith, 2001).

Water samples for chemical parameters collected seasonally. The water temperature, dissolved oxygen, electrical conductivity, $\mathrm{pH}$, depth and secchi depth were measured in situ. Because of the dry season, neither samples for Artemia nor water samples for some water parameters couldn't be taken in July, August and September.

The analysis for ammonnium-nitrogen $\left(\mathrm{NH}_{3}-\mathrm{N}\right)$, nitrate-nitrogen $\left(\mathrm{NO}_{3}-\mathrm{N}\right)$, nitrite-nitrogen $\left(\mathrm{NO}_{2}-\mathrm{N}\right)$, total hardness, alkalinity, orthophospate, concentrations of the lake were determined in The Central Laboratory of Soil, Fertilizer and Water Resources of Ministry of Food, Agriculture and Livestock according to Anonymous (1998). Chlorophyll $a$ concentrations were determined spectrophotometrically after filtration of water samples through Whatmann GF/C filter paper and extracted with aseton (Strickland and Parsons, 1972) and silica $\left(\mathrm{SiO}_{2}\right)$ concentrations were determined by fotometer with test kits which have ranges between 0.2-5mg..$^{-1}$ and 0.1-1.4 mg..$^{-1}$ concentration.

Statistical analysis were carried out by using SPSS 17 Statistic Program. Variance analysis (ANOVA) and Duncan multiple range test were computed to evaluate the differences in terms of the water quality parameters of the Lake (Kesici and Kocabaş, 2007).

\section{RESULTS AND DISCUSSION}

This study was put forward the status of Artemia population after 20 years in related to environmental factors in Tuz Lake. Artemia population was investigated for the first time in Tuz Lake by Başbuğ (1994) and our chosen stations had been same naturally with their stations because those were the ones that could be better to reach to the Lake. In our study, Artemia was found to be about 3,67 x10 individiual. $\mathrm{m}^{-3}$ in metanauplii form only in the 5. station at the end of the March (Table 1). Apart from that, during the research no Artemia was found in the stations. Apart from that, there was no cyst accumulation neither ashore nor surface of the lake during the study period. However, copepods mostly in nauplii stages and rotifers were encountered in low abundance in March and May at the 1th and 4th stations.

Table 1. Zooplankton abundance in stations and months in Tuz Lake (average abundance \pm standard deviation) $\left(\mathrm{x} 10^{3}\right)\left(\right.$ individual. $\mathrm{m}^{-3}$ )

\begin{tabular}{lccccc}
\hline & \multicolumn{5}{c}{ Stations } \\
\cline { 2 - 6 } Months & 1 & 2 & 3 & 4 & 5 \\
\hline March & $31.20 \pm 2.52$ & - & - & - & - \\
April & $4.03 \pm 0.37$ & $1.96 \pm 0.47$ & $1.94 \pm 0.34$ & $0.7 \pm 0.18$ & $0.36 \pm 0.27$ \\
May & $1.37 \pm 0.24$ & - & - & $0.36 \pm 0.48$ & - \\
\hline
\end{tabular}

Başbuğ (1994) determined the distribution of the Artemia population on the east side of the lake on a $10 \mathrm{~km}$ coast line which is the depth region of the lake and reported that the first generation of the population occured at the mids of the April and the adult forms at the end of the May. The second generation was observed in June and all of them reach to adult form in the July. In addition to this, it was indicated that the cysts of Artemia was collected out of the April-July period. The highest abundance in that study was about 106-114 individual.m ${ }^{-3}$ (Başbuğ, 1997; Başbuğ and Demirkalp, 1999). 
Tuz Lake is the reproduction site of waterfowls, especially flamingos (Phoenicopterus ruber) which is fed on zooplankton (Burgis and Morris, 1987). In 2014 year, it was reported thar the population of the flamingos reduced from 22000 fry to 2650 fry, because of the low water depth and insufficient feed in the lake (Balk1z, 2015). Our observations in the same year supplied this report. We could observe a few flamingos only in the last half of the March at the 1th station where we found mostly copepods nauplii.

The differences in the values of water temperature, salinity and electrical conductivity were found to be statistically significant according to the stations and months $(\mathrm{p}<0.05)$ (Figure 2). The differences in the values of $\mathrm{pH}$ were found statistically significant according to the months $(\mathrm{p}<0.05)$, insignificant according to the stations $(\mathrm{p}>0.05)$. The differences in the values of dissolved oxygen were insignificant both in the months and stations $(\mathrm{p}>0.05)$.

The highest average water temperatures were measured in 5th station about $30.60 \pm 0.55^{\circ} \mathrm{C}$ and $30.50 \pm 0.86^{\circ} \mathrm{C}$ in May and July, respectively. The lowest one was measured in November in the 4th station as $0.84 \pm 0.05^{\circ} \mathrm{C}$ (Fig. 2). Sayg1 and Demiralp (2002), measured the lowest water temperatures as $-3.8^{\circ} \mathrm{C}$ in November in Tuz Lake, the highest one was measured in June about $32^{\circ} \mathrm{C}$. In this study, the lowest water temperature was measured about $0.84 \pm 0.05^{\circ} \mathrm{C}$ in November and the highest values were about $30^{\circ} \mathrm{C}$ in June and July. In our study, we had never measured water temperature in minus values in the Lake. In the last 20 years, climatic conditions made differences in water temperatures.

During the study, the highest average dissolved oxygen values was determined as $7.55 \pm 0.31 \mathrm{mg} .1^{-1}$ in 3.station in November. In December and January, the lowest values of dissolved oxygen were measured as $1.63 \pm 0.13$ and $2.15 \pm 0.01 \mathrm{mg} . \mathrm{l}^{-1}$, respectively (Fig. 2). In Tuz Lake, the dissolved oxygen concentration was changed between $1.3 \mathrm{mg} . \mathrm{l}^{-1}-9.0 \mathrm{mg} . \mathrm{l}^{-1}$ in 1993-1994 years (Başbuğ and Demirkalp, 1997).

In this study, the highest average dissolved oxygen concentration was measured about $6.90 \mathrm{mg} . \mathrm{l}^{-}$ ${ }^{1}$ and it was lower than the value $9.0 \mathrm{mg} \cdot \mathrm{l}^{-1}$ that was measured 20 years ago. It is known that the Artemia populations can not tolerate dissolved oxygen below 2 mg..$^{-1}$ (Dhont and Van Stappen, 2003). In our study, the dissolved oxygen concentrations were under the toleration limits for Artemia in December and June.

In the study period, the average salinity values were ranged between $405 \pm 10$ g. $1^{-1}$ and $217 \pm 7$ g. $1^{-1}$ (Fig. 2). The highest average electrical conductivity values were found to be $214 \pm 1 \mathrm{mS} . \mathrm{cm}^{-1}$ at the 2 th and 3 th stations in May whereas the lowest value was about $118 \pm 1{\mathrm{mS} . \mathrm{cm}^{-1}}^{-1}$ in the 2 th station in November. uring the study, the average salinity values were changed between $217 \pm 7$ g..$^{-1}$ and $405 \pm 10$ g. $1^{-1}$. This range was about 114-395 g. $1^{-1}$ between 1993 and 1994 years (Başbuğ and Demirkalp, 1997). Uygun and Şen (1978) carried out hydrochemical investigation in 1976-1977 years in Tuz Lake and exhibited seasonal changes of salinity and they claimed two regions separated from each other by a thresold. One was the shallow main region the other part is the depth region and their salinity were about $249-274$ g. $1^{-1}$ and 66-76 g..$^{-1}$, respectively. In our study, the salinity values were found to be lower in the last two stations in the east side of the lake than the stations in the west side. However, it was observed that the salinity values were found to be higher according to Başbuğ and Demirkalp (1997) and Uygun and Şen (1978). Besides, there was no visible two regions in the lake as mentioned by Uygun and Şen (1978). In this study, the salinity values increased by the months. It was mentioned that increasing salinity causes decrease in plankton diversity and species richness (Hammer, 1993; Wen and Zhi-Hui, 1999). In our study, the electrical conductivity results were generally lower than the values in 1993-1994 years period. However, the lowest electrical conductivity value was same with Başbuğ and Demirkalp (1997).

During the study the average $\mathrm{pH}$ values were changed between $7.53 \pm 0.02$ and $7.89 \pm 0.01$ in the stations. In the Lake, $\mathrm{pH}$ values generally found to be lower according to Başbuğ and Demirkalp (1997) and were similiar to the results of Uygun and Şen (1978) except the 5th station whereas $\mathrm{pH}$ values were not increased above 7.9. This value was below the value that was indicated by Uygun and Şen (1978). 


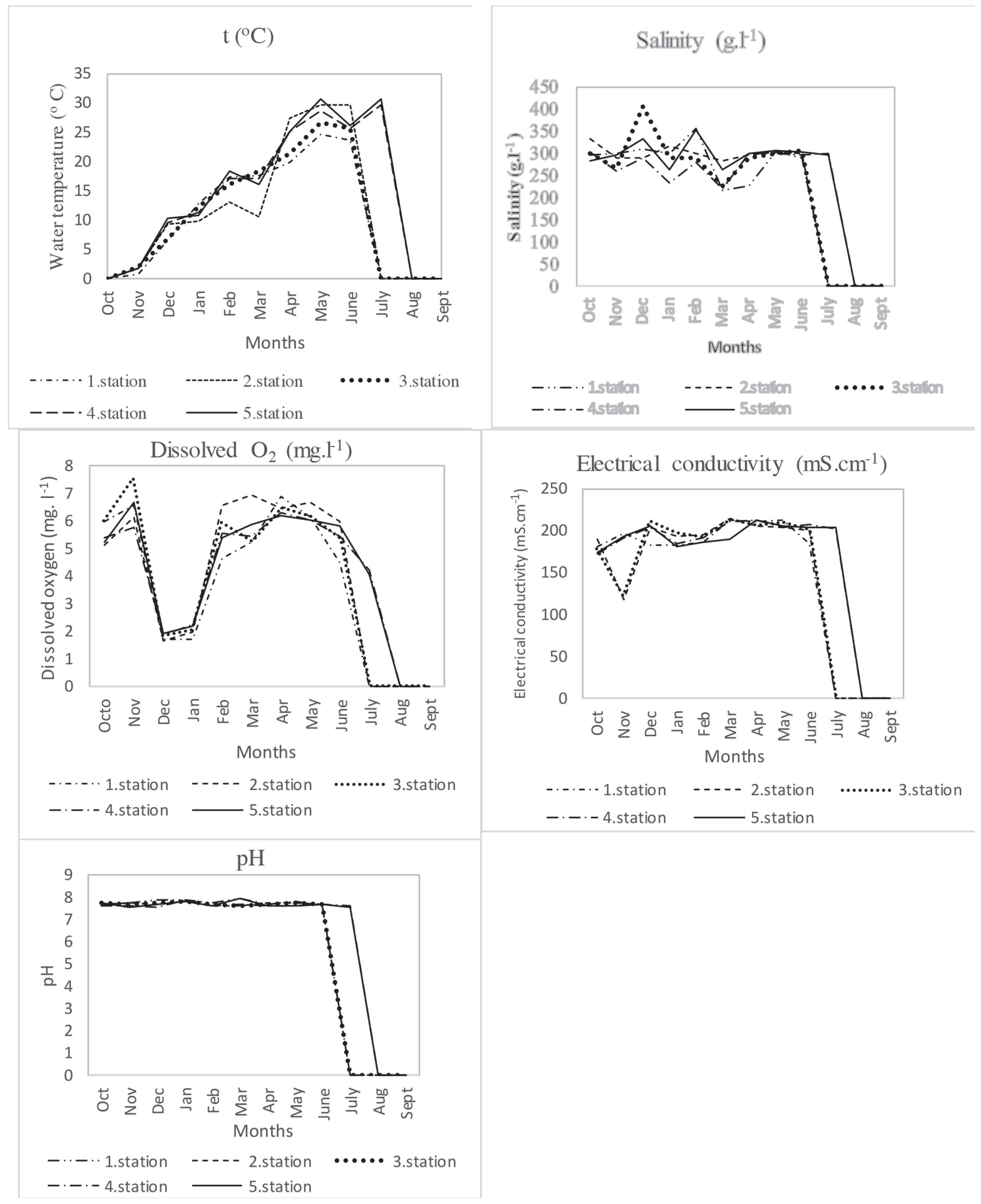

Figure 2. Average water temperature, salinity, dissolved oxygen, electrical conductivity and $\mathrm{pH}$ values in Tuz Lake during the study 
The differences in measured values of the average water depth and secchi depth in sampling periods (Fig 3 ) were found to be statistically significant according to months and stations $(\mathrm{p}<0.05)$. During the study the highest average water depth was about $28 \pm 1 \mathrm{~cm}$ at the 1. station in March, the lowest one was about $3 \pm 1 \mathrm{~cm}$ at the 2th station in January. In December, there was drawdown in all stations. In March, the bottom of the lake was mud by the rainfalls. In April, drawdown was observed again in the Lake. After May, salt stratification was occured at the Lake bottom and water depth decreased. In July, lake water was disappeared in the first three station by the evaporation. In the 4 th and 5 th stations, lake water was maintained by the low depth. Secchi depth values were same with the water depth in March, April and May in stations except 4th and 5th stations whereas $2 \pm 1 \mathrm{~cm}$ and $4 \pm 1 \mathrm{~cm}$, respectively. However, in spring and summer months the color of the lake water was changed to red in those last two stations.

It was reported that the average depths in the lake was about 30-40 cm in 1993-1994 years (Başbuğ, 1994). In 1995 years, it was about $70 \mathrm{~cm}$ in autumn and above $70 \mathrm{~cm}$ in spring in the shallow region whereas it was above $1 \mathrm{~m}$ in the depth region during the study (Çamur and Mutlu, 1995).

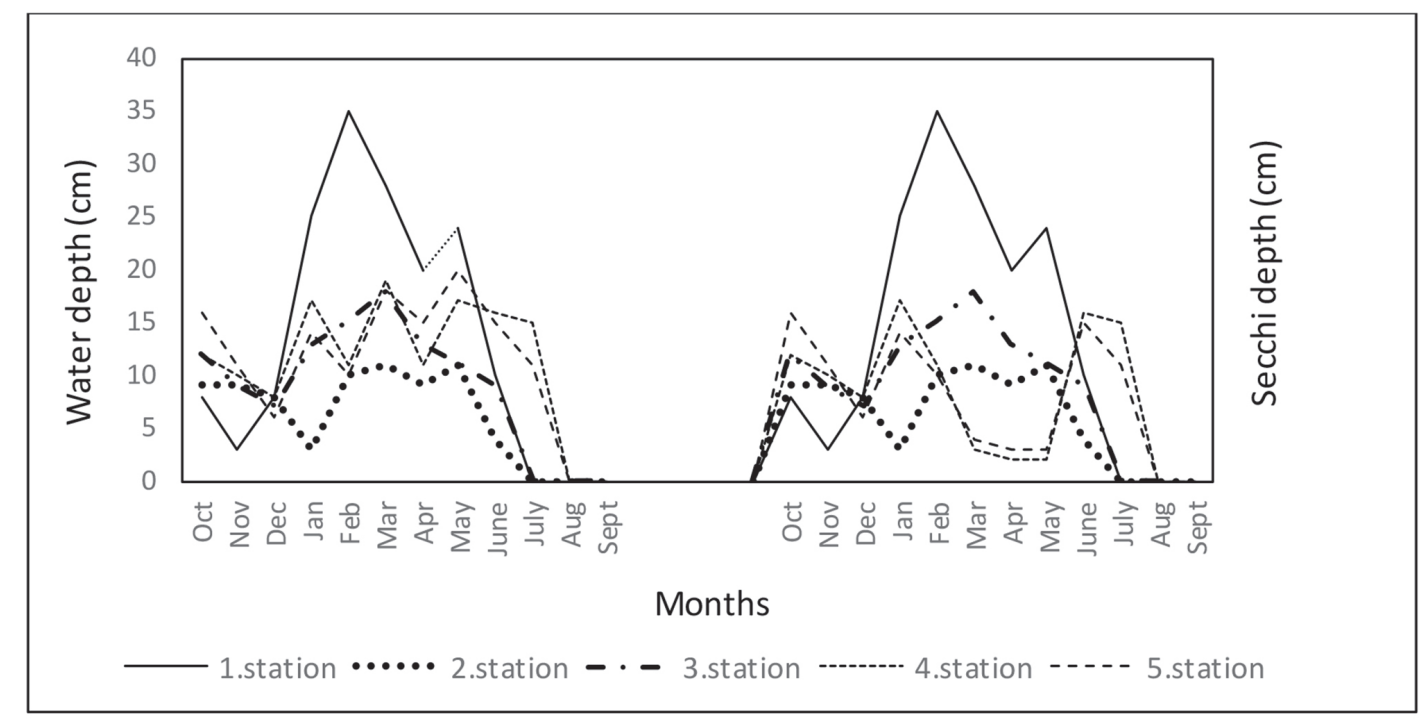

Figure 3. Average water depth and secchi depth values in Tuz Lake during the study

In 1996 years, it was measured about $50-80 \mathrm{~cm}$ in shallow region and about $1 \mathrm{~m}$ in the depth region (Kılıç and Uyanık, 2001). In our study, the depth was measured up to $20 \mathrm{~cm}$ in the east side (depth region), that was the lowest depth value according to the previous studies.

Besides, it was observed that in spring and summer the color of the lake water turned to red in 4th and 5 th stations in the same side. It was indicated that the source of this colouration, was algae, Dunelliella salina, blooms in the lake (Demir and Arısoy, 2013; Çakmak et al., 2014).

So, during the study secchi depths were all same with the water depths in the stations except in 4th and 5th stations whereas secchi depths fell and remained low in spring algal blooms.

Chlorophyll $a$, alkalinity, total hardness, orthophospate, ammonium nitrogen, nitrate nitrogen, nitrite nitrogen, silica were determined seasonally in Tuz Lake (Table 2). While the variations in the average concentrations of alkalinity, total hardness, nitrite nitrogen, silica were found to be significant statistically according to seasons and stations $(\mathrm{p}<0.05)$, average concentrations for nitrate nitrogen were insignificant $(p>0.05)$. The differences in the average concentrations of chlorophyll $a$ were statistically significant according to seasons $(\mathrm{p}<0.05)$, insignificant according to stations $(\mathrm{p}>0.05)$. 
Table 2. The average chlorophyll $a\left(\mu \cdot 1^{-1}\right)$, alkalinity $\left(\mathrm{mg} . \mathrm{l}^{-1}\right)$, total hardness $(\mathrm{FS})$, orthophospate $\left(\mathrm{mg} \cdot \mathrm{l}^{-1}\right)$, ammonium nitrogen $\left(\mathrm{mg} . \mathrm{l}^{-1}\right)$, nitrite nitrogen $\left(\mathrm{mg} . \mathrm{l}^{-1}\right)$, nitrate nitrogen $\left(\mathrm{mg} . \mathrm{l}^{-1}\right)$, silica $\left(\mathrm{mg} \cdot \mathrm{l}^{-1}\right)$ concentrations according to the months and stations (means $\left.\pm \mathrm{SD}\right)$

\begin{tabular}{|c|c|c|c|c|c|c|}
\hline \multirow{2}{*}{ Season } & \multirow{2}{*}{ Parameter } & \multicolumn{5}{|c|}{ Stations } \\
\hline & & 1 & 2 & 3 & 4 & 5 \\
\hline \multirow{10}{*}{ 声 } & & $0.56 \pm 0.25 b^{*}$ & & & & \\
\hline & Chloropyll $a$ & & $0.24 \pm 0.12 \mathrm{bB}$ & $2.70 \pm 1.19 \mathrm{aA}$ & $0.82 \pm 0.42 \mathrm{aB}$ & $1.08 \pm 1.14 \mathrm{aB}$ \\
\hline & & D & & & & \\
\hline & Alkalinity & $207 \pm 12 \mathrm{bA}$ & $147 \pm 12 \mathrm{abC}$ & $169 \pm 20 \mathrm{bBC}$ & $190 \pm 10 \mathrm{aAB}$ & $177 \pm 12 \mathrm{aB}$ \\
\hline & T.Hardness & $1419 \pm 312 \mathrm{~dB}$ & $1291 \pm 406 \mathrm{bB}$ & $2837 \pm 803 \mathrm{abA}$ & $2519 \pm 624 \mathrm{aA}$ & $3224 \pm 54 \mathrm{aA}$ \\
\hline & Orthophosp. & 0.00 & 0.00 & 0.00 & $0.004 \pm 0.001$ & $0.006 \pm 0.001$ \\
\hline & Amonnium-N & $2.25 \pm 0.10 \mathrm{bcB}$ & $2.50 \pm 0.20 \mathrm{bA}$ & $2.25 \pm 0.10 \mathrm{bB}$ & $1.70 \pm 0.05 \mathrm{bC}$ & $1.75 \pm 0.05 \mathrm{bC}$ \\
\hline & Nitrite-N & $0.007 \pm 0.00 \mathrm{bA}$ & $0.006 \pm 0.00 \mathrm{bA}$ & $0.008 \pm 0.015 \mathrm{bA}$ & $0.008 \pm 0.015 \mathrm{bA}$ & $0.006 \pm 0.002 \mathrm{aA}$ \\
\hline & Nitrate-N & $0.001 \pm 0.00$ & $0.003 \pm 0.000$ & $0.002 \pm 0.000$ & $0.003 \pm 0.001$ & $0.002 \pm 0.000$ \\
\hline & Silica & $0.15 \pm 0.01 \mathrm{cD}$ & $0.18 \pm 0.02 b D$ & $2.15 \pm 0.20 \mathrm{aC}$ & $4.30 \pm 0.05 \mathrm{aA}$ & $2.5 \pm 0.05 \mathrm{aB}$ \\
\hline \multirow{8}{*}{ 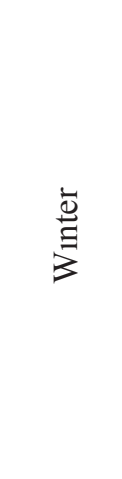 } & Chlorophyll $a$ & $1.65 \pm 0.40 \mathrm{aA}$ & $1.91 \pm 0.11 \mathrm{aB}$ & $2.02 \pm 0.40 \mathrm{abB}$ & $0.98 \pm 0.19 \mathrm{aB}$ & $1.64 \pm 0.49 \mathrm{aA}$ \\
\hline & Alkalinity & $177 \pm 54 \mathrm{bB}$ & $116 \pm 21 \mathrm{bD}$ & $189 \pm 8 \mathrm{bA}$ & $123 \pm 2 b C$ & $127 \pm 6 \mathrm{bC}$ \\
\hline & T.Hardness & $2874 \pm 158 \mathrm{bBC}$ & $1857 \pm 402 \mathrm{bC}$ & $2074 \pm 283 b C$ & $2366 \pm 270 \mathrm{aB}$ & $3145 \pm 268 \mathrm{aA}$ \\
\hline & Orthophosp. & $0.032 \pm 0.001$ & 0.00 & 0.00 & 0.00 & $0.002 \pm 0.002$ \\
\hline & Amonnium-N & $3.00 \pm 0.50 \mathrm{aA}$ & $2.00 \pm 0.50 \mathrm{bB}$ & $2.00 \pm 0.25 \mathrm{bB}$ & $2.20 \pm 0.76 \mathrm{aB}$ & $2.25 \pm 0.10 \mathrm{aB}$ \\
\hline & Nitrite-N & $0.006 \pm 0.003 \mathrm{bAB}$ & $0.013 \pm 0.002 \mathrm{bB}$ & $0.005 \pm 0.003 \mathrm{bAB}$ & $0.005 \pm 0.002 \mathrm{cB}$ & $0.008 \pm 0.001 \mathrm{aAB}$ \\
\hline & Nitrate-N & $0.002 \pm 0.000$ & $0.004 \pm 0.003$ & $0.001 \pm 0.01$ & $0.002 \pm 0.00$ & $0.002 \pm 0.001$ \\
\hline & Silica & $0.33 \pm 0.01 \mathrm{bB}$ & $0.21 \pm 0.02 \mathrm{bC}$ & $0.23 \pm 0.03 \mathrm{cC}$ & $0.50 \pm 0.10 \mathrm{bA}$ & $0.23 \pm 0.05 \mathrm{cC}$ \\
\hline \multirow{8}{*}{$\begin{array}{l}\text { 足 } \\
\text { 三 } \\
\text { की }\end{array}$} & Chlorophyll $a$ & $0.93 \pm 0.25 b C$ & $1.52 \pm 0.58 \mathrm{aB}$ & $2.15 \pm 0.24 \mathrm{abA}$ & $0.74 \pm 0.16 \mathrm{aC}$ & $1.33 \pm 0.64 \mathrm{aB}$ \\
\hline & Alkalinity & $236 \pm 45 \mathrm{abA}$ & $159 \pm 18 \mathrm{aC}$ & $157 \pm 15 \mathrm{bC}$ & $141 \pm 5 b C$ & $172 \pm 11 \mathrm{bB}$ \\
\hline & T Hardness & $2274 \pm 200 \mathrm{cB}$ & $1811 \pm 161 b C D$ & $2004 \pm 292 b B C$ & $1569 \pm 186 b D$ & $2761 \pm 389 \mathrm{aA}$ \\
\hline & Orthophosp. & $0.004 \pm 0.001$ & 0.00 & 0.00 & $0.002 \pm 0.001$ & $0.003 \pm 0.001$ \\
\hline & Amonnium-N & $2.00 \pm 0.50 \mathrm{cA}$ & $2.25 \pm 0.05 \mathrm{bA}$ & $2.30 \pm 0.02 \mathrm{bA}$ & $2.00 \pm 0.15 \mathrm{aA}$ & $2.25 \pm 0.25 \mathrm{aA}$ \\
\hline & Nitrite-N & $0.016 \pm 0.005 \mathrm{bA}$ & $0.013 \pm 0.005 \mathrm{bA}$ & $0.016 \pm 0.005 \mathrm{bA}$ & $0.020 \pm 0.00 \mathrm{aA}$ & $0.013 \pm 0.005 \mathrm{aA}$ \\
\hline & Nitrate-N & $0.010 \pm 0.00$ & $0.013 \pm 0.005$ & $0.009 \pm 0.00$ & $0.010 \pm 0.00$ & $0.009 \pm 0.00$ \\
\hline & Silica & $0.50 \pm 0.10 \mathrm{aB}$ & $0.46 \pm 0.05 \mathrm{aC}$ & $0.85 \pm 0.15 b B$ & $1.03 \pm 0.15 \mathrm{bA}$ & $0.70 \pm 0.10 \mathrm{bB}$ \\
\hline \multirow{8}{*}{ 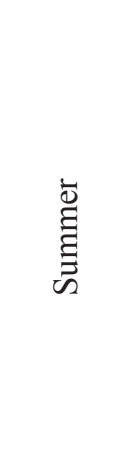 } & Chlorophyll $a$ & $0.45 \pm 0.51 \mathrm{bA}$ & $0.60 \pm 0.22 \mathrm{bA}$ & $2.53 \pm 0.52 \mathrm{aA}$ & $0.18 \pm 0.01 \mathrm{aAB}$ & $0.94 \pm 0.02 \mathrm{bA}$ \\
\hline & Alkalinity & $296.00 \pm 45 \mathrm{aA}$ & $158.66 \pm 18 \mathrm{aB}$ & $206.66 \pm 11 \mathrm{aB}$ & $172.00 \pm 10 \mathrm{aB}$ & $173.06 \pm 39 \mathrm{aB}$ \\
\hline & T.Hardness & $4410 \pm 408 \mathrm{aA}$ & $3645 \pm 804 \mathrm{aAB}$ & $3455 \pm 964 \mathrm{aAB}$ & $3132 \pm 622 \mathrm{aAB}$ & $2761 \pm 389 \mathrm{bB}$ \\
\hline & Orthophosp. & $1.07 \pm 0.05$ & 0.00 & 0.00 & 0.00 & 0.00 \\
\hline & Amonnium-N & $2.75 \pm 0.25 \mathrm{abB}$ & $2.75 \pm 0.05 \mathrm{aB}$ & $3.25 \pm 0.25 \mathrm{aA}$ & $1.30 \pm 0.10 \mathrm{cC}$ & $1.25 \pm 0.25 \mathrm{cC}$ \\
\hline & Nitrite-N & $0.266 \pm 0.14 \mathrm{aA}$ & $0.230 \pm 0.111 \mathrm{aA}$ & $0.266 \pm 0.047 \mathrm{aA}$ & $0.010 \pm 0.00 \mathrm{bB}$ & $0.043 \pm 0.057 \mathrm{aB}$ \\
\hline & Nitrate-N & $0.153 \pm 0.07$ & $0.100 \pm 0.010$ & $0.010 \pm 0.009$ & $0.096 \pm 0.132$ & $0.056 \pm 0.056$ \\
\hline & Silica & $0.32 \pm 0.11 \mathrm{aA}$ & $0.13 \pm 0.05 \mathrm{bB}$ & $0.13 \pm 0.0 \mathrm{cbB}$ & $0.13 \pm 0.05 \mathrm{bB}$ & $0.24 \pm 0.05 \mathrm{cAB}$ \\
\hline
\end{tabular}

*Means with different letters in the same column are significantly different $(\mathrm{p}<0.05)$

** Means with different letters in the same line are significantly different $(\mathrm{p}<0.05)$ 
Contrarily. the differences in the average concentrations of ammonium nitrogen were statistically significant according to stations $(\mathrm{p}<0.05)$. whereas insignificant according to seasons $(p>0.05)$. The average orthophospate concentrations were very low during the study and changed between 0.00-1.068 mg.1 ${ }^{1}$ in stations. The only and highest value was determined in the 1th station in summer. In the other seasons except autumn. orthophospate concentration was measured in the 1th station again. Orthophosphate concentrations were determined in very low concentrations in 4th and 5th stations in spring and autumn however it was not determined in the 2th and 3th stations during the study.

Chlorophyll $a$ concentrations are about 0.5-3.5 $\mu \mathrm{g} .1$ ${ }^{1}$ in Great Salt Lake of Utah whereas Artemia franciscana produce dormant cysts that are harvested and used in the aquaculture industry. In Urmia Lake (Iran), it is about 0.5-0.8 $\mu \mathrm{g} . \mathrm{l}^{-1} \quad$ (Eimanifar and Monthshebbi. 2007). Our results of chlorophyll $a$ measured seasonally and changed between $0.18 \pm 0.01 \mu \mathrm{g} . \mathrm{l}^{-1}$ and $2.70 \pm 1.19 \mu \mathrm{g} . \mathrm{l}^{1-1}$ during the study. Those concentrations were lower than Big Salt Lake and higher than Urmia Lake. Tuz Lake is oligotrophic. with those annual chlorophyll $a$ levels (Anonymous. 2015). It is mentioned that temperature. quality and quantity of food source will influence the availability of Artemia populations (Wurtsbaugh and Gliwicz. 2001).

In Tuz Lake, seasonally average alkalinity values were changed between $296.00 \pm 45.07 \mathrm{mg} . \mathrm{l}^{-1}$ and $116.00 \pm 21.16 \mathrm{mg} \cdot \mathrm{l}^{-1}$. Because of the dominancy of the bicarbonate ions. alkalinity is higher in the Lake correspondingly $\mathrm{pH}$ range was stayed between $7.53 \pm 0.02$ and $7.89 \pm 0.01$ during the study (Erençin and Köksal. 1981). It was declared that higher alkalinity lead to supress of diversity and species richness in water bodies (Zhao and He. 1999). From this point of view, it can be talled that alkalinity as well as salinity influences biological diversity (Wen et al.. 2005). However, total hardness values were also higher in the Lake and it was reported that there is a strong correlation among increasing salinity, alkalinity and hardness in water bodies (Wen and Zhi-Hui. 1999).

Uygun and Şen (1978) were investigated the hydrochemical features of Tuz Lake and they reported that they didn't determine ortophosphate and ammonium nitrogen concentrations in the Lake water. In our study. orthophospate was determined in low concentrations. up to $1.06 \mathrm{mg} . \mathrm{l}^{-1}$ in 4 th. 5 th and 1 th stations in some months. However. ammonium nitrogen concentrations were found to be high in the all stations during the study. Anonymous (2013) was determined the ammonium nitrogen concentrations in the influent Brooks of the Lake such as Peçenek Brook (0.035-0.038 mg. $\left.\mathrm{l}^{-1}\right)$. Değirmenözü Brook (0.026-0.032 mg. $\left.1^{-1}\right)$. İnsuyu Brook (0.018-0.024 mg..$\left.^{-1}\right)$ and Main Discharge Canal ( 0.069-0.071 mg. $\mathrm{l}^{-1}$ ) of State Water Works in April-May 2013. We can say that the source of ammonium nitrogen presence in the Lake was mainly antropogenic.

Uygun and Şen (1978) determined silica in the Lake. In our study. the highest silica value was adjusted with the lowest silica value with the previous study. so we can say that silica values decreased in the Lake.

\section{CONCLUSION}

It was mentioned that there was two regions in the lake. One is shallow main region and the other is depth region (Uygun and Şen. 1978). Basbuğ and Demirkalp (1997) supported this by their results. They indicated that there were differences in $\mathrm{pH}$ salinity and temperature values between two regions. Also in the depth region whereas Artemia populations located. electrical conductivity. salinity values were lower and in summer and spring months dissolved oxygen and depth were higher. In our study depth decreased to 20 $\mathrm{cm}$ in the depth region and when it was compared with the previous studies depth level fell down in September 2013-July 2014.

By this study, it was observed that the district differences were dissappeared between two regions by the global warming that caused to lack of raining. Therefore, climatic conditions induced the changes in the Lake's physical and chemical water features of depth region where the Artemia populations located in the past. Especially. the changes of water temperature and salinity limited Artemia growing in the Lake. Factors caused the current status of the Tuz Lake were unconscious use of groundwaters reduction of the basin. precipitation caused by global warming and decreased of rainfalls. the surrounding settlements. agriculture activities and brooks and canal influents carrying 
pollution changed some physical and chemical water parameters of the Tuz Lake and caused the dismissed of the Artemia which is the dominant zooplankton of salt lakes. Instead of it. copepods nauplii and rotifers determined in a few stations. Tuz Lake should be monitored physically. chemically and biologically in long term. Besides. Tuz Lake was compansated salt requirement of the country because of this. Lake is under threat and new saltpans shouldn't be constructed. They

\section{REFERENCES}

Anonymous. 1998. Standard Methods for the Examination of Water and Wastewater. AWWA. WEF. Washington DC.

Anonymous. 2007. Biyolojik Çeşitliliğin Tespiti: Tuz Gölü Projesi. Özel Çevre Koruma Kurumu Başkanlığı. Ankara.

Anonymous. 2013. Foça. Gökova. Datça-Bozburun. KöyceğizDalyan. Fethiye-Göcek. Patara. kaş-Kalkan-Kekova. Belek. Göksu Deltası. Ihlara. Tuz Gölü. Gölbaşı. Uzungöl. Pamukkale ve Saros körfezi Özel Çevre Koruma Bölgelerinde Su Kalitesinin İzlenmesi ve özel çevre koruma Bölgelerinde İşletilmekte Olan Atıksu Arıma Tesislerinin Verimliliğinin İzlenmesi Projesi. ALKA-TVKGM-Rapor No:R_ÖÇK-RO2.

Anonymous. 2015. Surface waters quality regulations (in Turkish). Orman ve Su İşleri Bakanlığı. Resmi Gazete. Ankara.

Balkız Ö. 2015. Tuz Gölü: Flamingolar. Atlas Dergisi. sayı 264.

Başbuğ Y. 1994. Tuz Gölü'nde Yaşayan Artemia salina (L.. 1758)'nın Biyolojik Özellikleri ve Sistlerinden Laboratuar Koşullarında Larva Üretilmesi. Yüksek Lisans Tezi. Hacettepe Üniversitesi Fen Bilimleri Enstitüsü.81 s.

Başbuğ Y. Demirkalp FY. 1997 A Note on the Brine Shrimp Artemia in Tuz Lake. Hydrobiologia. 263: 45-51.

Başbuğ Y. 1999. Tuz Gölü’nde Yaşayan Artemia salina (L.. 1758)'nin Bazı Biyolojik Özellikleri. Turkish Journal of Zoology. 23(2): 617-624.

Burgis JM. Morris P. 1987. The Natural History of Lakes. Saline and Soda Lakes 218: 141-163.

Çakmak YS. Kaya M. Asan-Ozusaglam M. 2014. Biochemical Composition and Bioactivity Screening of Various Extracts From Duneliella salina. A Green Alg. EXCLI Journal 13: 679-690.

Çamur MZ. Mutlu H. 1995.Tuz Gölü’ndeki mineral çökeliminin termodinamik değerlendirilmesi. Türkiye Jeoloji Bülteni. 38: 2. 67-73.

Demir A. Arısoy M. 2013. Tuz Gölü Mikrobiyolojik Çeşitliliğinin Ekonomik Değer Analizi: Duneliella salina Örneği. Biyoçeşitlilik Sempozyumu. 22-23 Mayıs. Marmaris. Bildiri Kitab1. 53-55. will give harm to the feeding cells of the Lake. So, the lake water will reduce with new saltpan constructions.

\section{ACKNOWLEDGEMENTS}

This research supported by Ankara University (grant no.13B6055001). We are grateful to Prof. Dr. Nilsun Demir for her assistance in the laboratory work.

Demir N. 2007. Changes in the phytoplankton community of a coastal. hyposaline lake in western Anatolia. Turkey. Limnology Asia/Oceania Report. 8: 337-342.

Dhont J. Van Stappen G. 2003. Biology. tank production and nutritional value of Artemia. In: Stottrop JG and Mc Evoy LA (eds). Live Feeds in Marine Aquaculture. Blackwell Publishing. 65-121.

Edmondson WT. 1959. Fresh-Water Biology. John Wiley and Sons. New York.

Edmondson WT. Winberg GG. 1971. A manual on methods for the assesment of secondary productivity in fresh waters. Blackwell Scientific Publications. Oxford.

Eimanifar A. Monthshebbi F. 2007. Urmia Lake: a Brief Review. Saline Systems. 3:5.

Erençin Z. Köksal G. 1987. İçsular Temel Bilimleri Limnology. Ankara Üniversitesi Veteriner Fakültesi Yayınları. 375. Ankara.

Hammer UT. 1993. Zooplankton distribution and abundance in saline Lakes of Alberta and Saskatchewan. Canada. International Journal of Salt Lake Resources. 2(2): 111-132.

Kesici T. Kocabaş Z. 2007. Biyoistatistik. Ankara Üniversitesi Eczacılık Fak. Biyoistatistik Yayın No:94. Ankara.

Kılıç AM. Uyanık E. 2001. Tuz Gölü’nde Oluşan Kirlenmenin Göl Üzerindeki Etkilerinin Araştırılması. 4. Endüstriyel Hammaddeler Sempozyumu.18-19 Ekim. İzmir.

Koste W. 1978. Rotatoria. Die Radertiere Mitteeuropas. 2th ed. Gebruder Borntraeger. Berlin.

Mc Cauley E. 1984. The estimation of the abundance and biomass of zooplankton in samples. In: Downing JA and Rigler FH (eds). A manual on methods for the assembling of secondary productivity in fresh waters 2 th ed. Blackwell Scientific Publications. Oxford.

Persoone G. Sorgeloos P. 1980. General aspects of the ecology and biogeography of Artemia: 3-24 In: Persoone G. Sorgeloos P. Roels $\mathrm{O}$ and Jaspers E (eds). The Brine Shrimp Artemia.Vol.3. Universa Press. Wetteren. Belgium. 
Sayg1 YB. Demirkalp FY. 2002. Effects of temperature on survival and growth of Artemia from Tuz Lake. Turkey. The Israeli Journal of Aquaculture-Bamidgeh 54(3). 125-133.

Smith DG. 2001. Pennak's freshwater invertebrates of the United States:Porifera to Crustacea. John Wiley\&Sons. United States.

Strickland JDH. Parsons TR. 1972. A practical handbook of seawater analysis. 2nd ed. Bulletin of Fish Resources Board Can. Ottowa.

Tanyolaç J. 2006. Limnoloji. Basım ve Yayın San. Tic. Ltd. Şti. 4. Bask1. Ankara.

Uygun A. Şen E. 1978. Tuz Gölü Havzası ve Doğal Kaynakları I: Tuz Gölü Suyunun Jeokimyası. Türkiye Jeoloji Kurumu Bülteni. 21; 113-120.

Wen Z. Zhi-Hui H. 1999. Biological and ecological features of inland saline waters in North Hebei. China. International Journal of Salt Lake Research. 8: 267-285.
Wen Z. Mian-Ping Z. Xian-Zhong X. Xi-Fang I. Gan-Lin G. ZhiHui H. 2005. Biological and ecological features of saline lakes is northern Tibet. China. Hydrobiologia. 541:189-203.

Wetzel RG. Likens GE. 1991. Limnological analysis. $2^{\text {nd }}$ ed. Springer Verlag. New York.

Williams WD. 1998. Salinity as a determinant of the structure of biological communities in salt lakes. Hydrobiologia. 381: 191-201.

Wurtsbaugh WA. Gliwicz ZM. 2001. Limnological control of brine shrimp population dynamics and cyst production in the Great Salt Lake. Utah. Hydrobiologia. 486:119-132.

Zhao W. He ZH. 1999. Biological and ecological features of inland saline waters in North hebei. China. China. International Journal of Salt Lake Research. 8: 267-285. 